School of Finance

University of St.Gallen

THE EXPOSURE OF MICROFINANCE INSTITUTIONS TO FINANCIAL RISK

THOMAS GIETZEN

WORKING PAPERS ON FINANCE No. 2015/06

SWISS INSTITUTE OF BANKING AND FINANCE (S/BF - HSG)

MARCH 2015 


\title{
The Exposure of Microfinance Institutions to Financial Risk Thomas Gietzen*
}

March 30, 2015

\begin{abstract}
This study examines the exposure of microfinance institutions to liquidity, interest rate and foreign exchange (FX) risk. It builds on a manually collected set of data on FX positions and the maturity structure of assets and liabilities of the largest microfinance institutions worldwide. The data suggests that microfinance institutions in the sample, on average, face no liquidity risk and that exposure to FX risk is lower than commonly assumed. Linking risk exposure to institutional characteristics, I find that legal status and regional affiliation are correlated with risk exposure while regulatory quality is not.
\end{abstract}

JEL Classification: G21, G32, O16

Keywords: Microfinance, Financial Risk, Liquidity Risk, FX Risk, Ownership, Regulation

${ }^{*}$ KfW Development Bank, Evaluation Department, Palmengartenstrasse 5-9, 60325 Frankfurt am Main, Germany, Thomas.Gietzen@kfw.de, $+49(0) 69-74316239$.

I would like to thank Martin Brown and Eva Terberger for valuable advice and guidance. I would also like to thank seminar participants at the University of St.Gallen and the University of Göttingen.

Disclaimer: Any views or opinions presented in this paper are solely those of the author and do not necessarily represent those of the company. 


\section{Introduction}

Modern microfinance, in the form of specialized institutions that target their activities to groups otherwise barred from formal financial services, has been widely accepted as a viable business model. After the very successful initial years without any major crisis, the microfinance community had even come to believe that microfinance, due to its unique business model, is resilient to most traditional risks in banking (Winkler and Wagner 2012). However, a recent concourse of crises - among others in Bosnia and Herzegovina (2008), Pakistan (2008-09) and India (2010) - has brought down this level of optimism and triggered a sharp increase in the donor community's effort to mitigate risk in microfinance. Yet, there still exists little evidence on the true exposure of microfinance institutions to financial risk. In particular, three prominent types of risk - liquidity risk, interest rate risk and foreign exchange (FX) risk - that are of great concern in the standard banking literature, have gained little attention from the microfinance research community up to now. The lack of quantitative evidence is in sharp contrast to the donor community spending considerable amounts of resources on mitigating financial risks in microfinance, based on little more than narrative evidence.

This study uses a new hand-collected data set on the maturity structure of assets and liabilities and FX positions from microfinance institutions' (MFIs) financial reporting files to quantify the exposure of MFIs to financial risk. In the absence of a comprehensive microfinance data source to study financial risk other than credit risk, I use the new data to firstly provide evidence on the total risk exposure of MFIs to liquidity risk, interest rate 
risk and FX risk. Secondly, I examine how exposure to these three risks is related to the legal statuses of MFIs (Banks vs. Non-Banks and NGOs, Credit Unions and Cooperatives) and the legal environments in which they operate. The evidence presented is an attempt to help streamlining the practitioner community's future actions towards risk in microfinance.

The current risk mitigation strategy is based on the common belief that MFIs are exposed to high levels of FX risk and rather low levels of liquidity risk, while interest rate risk is often not commented on at all. The belief itself stems from the type of business model that standard MFIs run, which often differs substantially from that of more commercially oriented banks. MFIs tend to lend short with small ticket sizes (Winkler and Wagner 2012). Unlike purely commercial banks, MFIs are also able to borrow long from development financial institutions (DFIs), usually at concessionary terms. However, long-term DFI funding tends to be denominated in foreign currency potentially creating a mismatch to the short-term local currency lending. At the same time, there are opposing arguments that suggest treating this common narrative with care. Firstly, deposit-taking MFIs have increased their share of funding from deposits (Lützenkirchen and Weistroffer 2012). Local currency deposits are a potential way to mitigate FX risk but at the same time may introduce a new source of liquidity risk to MFIs' portfolios. Secondly, many MFIs operate in widely euroized or dollarized economies in which large parts of all assets - and not only liabilities - are denominated in hard currency to balance the effect of hard currency borrowing (examples include Bosnia and Herzegovina or Ecuador). Hence, customers in many economies consign deposits in both hard and local currency (examples include Serbia 
for the Euro and Cambodia for the US Dollar). Both the effects of deposits and euroization or dollarization are not immediately obvious. There is little evidence on the role of deposits in determining liquidity risk for MFIs in developing countries, where deposit insurance mechanisms might not always be available or fully effective to stabilize core deposits. Moreover, with the existing data, there is no comprehensive evidence as to what extent MFIs also maintain hard currency assets and not only liabilities.

This study is the first to disentangle common narratives about MFIs' exposure to the three risks and to link risk exposure to the regulatory environment and an MFI's legal status. A first result concerns the determinants of a more detailed risk reporting of MFIs. In dividing the base sample of 309 institutions into MFIs that report sufficiently detailed data to construct measures of financial risk and MFIs that do not, I find that NGOs, Credit Unions and Cooperatives ${ }^{1}$ are, on average, less likely to report than Banks. Also, being an Eastern European MFI makes MFIs more likely to report details on financial risk exposure.

Results on the overall risk exposure of the microfinance sector using a large subset of all MFIs in the market show that concerns about MFIs' liquidity risk exposure are not warranted. MFIs' short term assets ( $\leq 30$ days) surpass short-term liabilities threefold on average (a negative level of maturity transformation). Due to the imbalanced maturity structure of MFIs' balance sheets, exposure to interest rate risk is substantial. The average difference between interest repricing assets and liabilities over a one year horizon stands at $27 \%$ of total assets. On the other hand, results also show

\footnotetext{
${ }^{1}$ The three legal statuses are grouped together to achieve more powerful estimates.
} 
that average exposure to FX risk is lower than most market observers tend to believe. Low FX risk exposure is the result of counterbalancing asset and liability positions. MFIs fund a considerable share of their assets with FX liabilities (28\%), but the average share of FX assets also stands at $28 \%$ and offsets a large amount of exposure to FX funding. Using a very conservative measure of FX risk, i.e. not netting out differences between single currencies, MFIs are only exposed to an average total difference between their foreign currency assets and liabilities (Net Open Position) of $4.5 \%$ of total assets. While a few MFIs with considerable exposure do exist, most exhibit only very low levels of FX risk. Eastern European MFIs keep the highest share of FX assets and liabilities on their books, but MFIs from East Asia and the Pacific face the highest mismatch between FX assets and liabilities. Overall, results on total risk exposure suggest that an extension of current systemic policy measures against liquidity and FX risk would not help relax actual constraints that keep MFIs from extending their lending towards microfinance clients in volume or from granting longer-term credit.

Finally, I provide novel evidence on whether institutional features of MFIs are systematically correlated with levels of financial risk exposure. I focus on an MFI's legal status and the regulatory environment which MFIs operate in (two key policy variables). Thus, results contribute to the discussion on which institutional features of MFIs are most suitable to attain social outreach while at the same time containing risk. I find that, in line with most of the previous research, the strength of local regulation plays no role in determining exposure to financial risks. An MFI's legal status, however, does correlate with the exposure to liquidity and FX risk. Banks face 
higher liquidity risk than Non-Banking Financial Institutions (NBFIs), not only due to their larger share of funding via deposits. NGOs, Credit Unions and Cooperatives are exposed to more FX risk, although their share of funding via FX liabilities is lower, which suggests an inferior ability to mitigate FX risk. Results also show that regional affiliation is correlated with levels of risk exposure. I suggest that, despite investors' unifying approach to microfinance worldwide, different traditions in regional microfinance markets still influence MFIs' business models up to this day.

\section{Literature}

At first glance, raw data confirms the common narrative of high FX and low liquidity risk exposure. A considerable amount of the aggregate microfinance sector's liabilities is indeed cross-border, public, long-term funding. In 2011, the amount of cross-border funding for the sector was between 15 to 25 billion US Dollars depending on the source of the estimates and constituted about one fifth of the sector's total asset size (Reille, Rozas, and Forster 2011; Lahaye, Rizvanolli, and Dashi 2012). The largest share of cross-border funding comes as debt-type instruments (55\%). In 2004 more than $90 \%$ of all cross-border debt funding towards MFIs was denominated in Euro or US Dollar, i.e. generally in non-local currency for the MFIs (Lahaye, Rizvanolli, and Dashi 2012). However, literature that translates the funding structure into quantitative estimates of financial risk in the microfinance industry has

so far been almost non-existent. In particular, there is no reliable evidence on whether the microfinance industry's exposure to the three financial risks 
should be a matter of concern at all. Abrams and Prieur (2011) is an exception with regard to FX risk from the practitioner community. Their study concludes that FX risk in the sector is considerable, but the authors do not show the sensitivity of results to the study's very conservative definition of prudent levels of exposure.

The lack of evidence is most likely due to data restrictions. The existing databases feature standard indicators of credit risk but fall short with respect to measures of other financial risks. In particular, the composition of funding (the share of deposits and borrowings) is easily computed from existing databases, but the actual maturity patterns of the types of funding and of MFIs' assets are unknown. Empirical evidence is additionally hampered by accounting standards and quality of publications, which differ widely among microfinance providers globally. Hence, most of the literature on financial risk in microfinance is exclusively concerned with MFIs' management practices, in particular FX risk management $2^{2}$ Crabb (2004) notes that conventional methods of hedging FX risk are often inapplicable to MFIs. This shortage of classic countermeasures against FX risk gave rise to alternative instruments MFIs use to manage FX risk, like back-to-back lending or letters of credit (Featherstone, Littlefield, and Mwangi 2006).

Despite conflicting narratives on risk exposure and an apparent lack of empirical evidence, the international community has taken systemic actions to mitigate exposure with regard to financial risks. For example, DFIs have recently pushed to develop methods of local currency borrowing for MFIs.

\footnotetext{
${ }^{2}$ Brom $(2009)$ is a non-quantitative guideline to risk exposure measurement of the three financial risks in this study.
} 
One example is the TCX fund that provides OTC derivatives to hedge FX risk and spans 70 primarily small currencies (www.tcxfund.com). Another example is the African Local Currency Bond Fund (www.alcbfund.com) that promotes local currency borrowing for African MFIs. Regarding liquidity risk, the donor community has established the Microfinance Enhancement Facility, which is a 500 million US Dollar facility aimed at supporting MFIs facing liquidity shortages in the wake of the 2008 financial crisis (www.meffund.com). Many DFIs also tilt refinancing for MFIs towards very longterm borrowing or equity-type instruments in order to explicitly alleviate MFIs' burden of maturity transformation, often in the hopes of therewith promoting a higher lending volume and longer-term lending.

In addition to immediate risk mitigation measures, the international donor community frequently advocates the transformation of non-private MFIs and NGOs into private shareholder-owned firms (Mersland and Strøm 2008). This is at least partly due to the belief that shareholder-owned firms feature a superior ability to manage risk. For the same purpose, the donor community has devoted many resources to developing local financial sector regulation. Thus, to get a complete picture of the determinants of financial risk exposure and the potential impact of donors' engagements, this study also investigates the impact of an MFI's legal status and the regulatory environment on risk exposure. Again, existing evidence with regard to financial risks is scarce. The microfinance mission-drift literature that was originally concerned with the effect of commercialization on outreach (by the share of female clients, rural clients, etc.) has spurred another strand of literature that links institutional features of MFIs and regulation to outreach and 
profitability measures. Existing evidence suggests a rather small impact of the regulatory environment and MFIs' legal statuses on outreach and performance. Examining, among other things, the effects of bank regulation on financial performance and outreach of MFIs, Mersland and Strøm (2009), using a data set of MFI ratings, find that regulation does not affect outreach and financial performance. Similarly, Hartarska and Nadolnyak (2007) find no effect of bank regulation on outreach and financial performance. Regarding an MFI's legal status, Mersland and Strøm (2008) find only small differences between private, shareholder-owned firms and non-profit institutions with respect to social orientation and performance. Conversely, Cull, Demirgüç-Kunt, and Morduch (2011) find that more profit-oriented MFIs tend to reduce outreach when faced with stricter supervision, while institutions with a weaker commercial focus tend to reduce profitability. Trying to consolidate the co-existence of different legal statuses among MFIs, Mersland (2009) finds that cost structures vary among legal statuses and that a co-existence of different ownership types might serve microfinance clients best. Still, changes in performance and outreach due to different legal statuses or changes in the regulatory environment should always be weighed against possible effects on risk exposure. Due to a lack of quantitative evidence, previous studies were not able to control for risks other than credit risk. The results of this study thus add to earlier analyses by linking MFIs' financial risk exposure to institutional characteristics and regulation of MFIs and by suggesting simple measures of financial risk that could be used complementarily to the existing measures of credit risk. 


\section{Data}

To construct measures of financial risk, I manually extract a set of data from publicly available - either via the MIX database or via any other online source - audited financial reporting files of MFIs from fiscal year-end 2011. The MIX database is the most extensive and widely used set of data in the microfinance industry. Yet, the database does not contain information on the maturity structure of assets and liabilities (A\&L) or in any closer detail on FX positions of MFIs. To my knowledge, no other comprehensive effort to gather data on MFI's A\&L maturity structure and FX positions exists. In order to cover a relevant fraction of the market, the base sample for which financial reporting files are considered consists of the 309 largest (by total assets) MFIs in 2011 from the MIX database. The base sample covers more than $60 \%$ of the total asset volume of MFIs registered in the MIX database (even excluding one outlier at the top). Table 1 summarizes the availability of financial reporting files and whether they contain detailed information on liquidity, interest rate or FX risk. I am able to construct at least one of the risk measures for about half of the original sample of 309 MFIs.

Table 1. Availability of Audited Financial Statements

\begin{tabular}{ll}
\hline Yes (information on any of the risks available) & $150(49 \%)$ \\
Yes (no information on any of the risks available) & $89(29 \%)$ \\
No & $57(18 \%)$ \\
Other Language (other than English, Spanish, French, German) & $13(4 \%)$ \\
\hline Baseline Sample: 309 largest MFIs by total asset volume in MIX in 2011.
\end{tabular}




\subsection{Risk Measures}

\subsubsection{Liquidity Risk}

This study follows the Basel Committee on Bank Supervision's (BCBS 2008) definition of liquidity risk as the risk that a financial institution (FI) is unable to meet its immediately outstanding obligations or is unable to fund increases in the volume of its assets without incurring unacceptable losses. The BCBS definition tacitly comprises a demand and supply side of liquidity. To form an idea of future expected cash outflow (i.e. liquidity demand) and expected cash inflow (i.e. liquidity supply), regulators have increasingly been using maturity profiles instead of simple static measures of liquidity (Van Greuning and Brajovic-Bratanovic 2009). Maturity profiles group A\&L into different time bands to capture the timing of expected (or on a simpler notion contractual) future cash in- and outflows. Additionally, the Basel regulation weighs $\mathrm{A} \& \mathrm{~L}$ by the liquidity of the respective security markets. In light of this, the most recent regulatory guideline, Basel III, defines two complementary minimum standards of liquidity risk provision (BCBS 2013). The Liquidity Coverage Ratio (LCR) is intended to measure and promote short-term resilience to liquidity problems, while the Net Stable Funding Ratio (NSFR) intends to measure long-term ( $\geq$ one year) liquidity needs and supply.

To study liquidity risk in microfinance, I establish a liquidity risk measure that relies on maturity profiling based on the logic of Basel III's LCR. The measure can be composed solely from public financial reporting data and is attuned to capture the risk from the prevailing business model in 
microfinance in a comparable way for a global sample of MFIs. For most MFIs, short-run liquidity supply on the asset side of the balance sheet is mainly the amount of loans that mature over the short-term, cash and balances with the central bank. Most of an MFIs' assets are on-balance sheet, fixed-maturity loans. Securitization in this sector is still underdeveloped, especially for the smaller MFIs (Brom 2009) and most MFIs do not hold considerable amounts of marketable securities, sovereign debt or corporate debt that could be sold off in a liquidity crunch. Therefore, I use the remaining contractual maturity of all assets with a uniform weighting instead of determining single market liquidity for each asset class 3 On the liability side, the crucial difference between expected and contractual maturity concerns deposits. Basel III assumes that a share of demand deposits stays with the financial institution (FI) for longer than the earliest contractual draw-down date (core deposits). Yet, the history of banking crises shows that even conservative assumptions about core deposits can collapse quickly in a particularly dire business environment and in the absence of effective deposit insurance mechanisms. To employ a more conservative measure than Basel III, I use contractual maturity only, which means that the full amount of demand deposits is possibly due in the short-run. Finally, the Liquidity Coverage $(L C)$ that resembles Basel III's LCR is the ratio of short-term (by remaining time to contractual maturity) assets and liabilities within a one month time band.

\footnotetext{
${ }^{3}$ The type of liquidity risk captured in this study is thus closely related to the concept of funding risk.
} 


$$
L C=\frac{\text { Short-Term Assets (One Month) }}{\text { Short-Term Liabilities (One Month) }}
$$

Short-term assets notably include maturing loans, central bank reserves, cash and all other current financial assets, as well as short-term investments. If listed on the balance sheet, I exclude property and equipment, provisions, deferred tax assets, the residual category of other assets, restricted funds, intangible assets and goodwill, and investments in associates from the liquidity coverage measure, due to their largely unclear role in liquidity provision and varying accounting standards. In any case, these positions never constitute a sizable share of the total asset volume. For the denominator, I do not exclude any liability classes from the measure of short-term liquidity. The ratio does not consider off-balance sheet (OBS) exposure. A value of one indicates a perfect match for $\mathrm{A} \& \mathrm{~L}$ maturities and higher values indicate lower liquidity risk.

\subsubsection{Interest Rate Risk}

Interest rate risk is the exposure of an FI to movements in the interest rate from either an economic value or a cash flow (earnings) perspective (BCBS 2004). This study focuses on the earnings perspective and therefore on repricing risk. Repricing risk is the most basic form of interest rate risk and results from a mismatch in volume of so-called rate-sensitive assets and liabilities (RSA and RSL) for which interest rates are repriced within a certain time period. Repricing occurs because fixed-rate positions mature, interim 
or partial payments are due and interest payments change on a contractual basis or for floating-rate instruments (Koch and McDonald 2009). I employ the so-called Gap Method (also: Repricing Model), which is a simple cash flow based approach to measure interest rate risk. I construct the Cumulative Interest Gap $(C I G)$ using the absolute value of the cumulated gap between RSA and RSL over a one year horizon. The gap is normalized by the total amount of assets 4

$$
C I G=\frac{\mid(\text { RSA } \leq \text { One Year })-(\text { RSL } \leq \text { One Year }) \mid}{\text { Total Assets }}
$$

A higher gap between repricing A\&L indicates a higher exposure to interest rate risk. However, the measure does not capture the fact that MFIs with the same $C I G$ can still be exposed to more or less volatile interest rate environments (BCBS (2004) discusses other dimensions of interest rate risk).

Determining a repricing profile requires (1) defining RSA and RSL and (2) grouping RSA and RSL into repricing time bands.5 To determine the

\footnotetext{
${ }^{4}$ The literature that popularized using Gap Models between RSA and RSL dates back to the early 1980's. For an early example see Brewer (1985). Gap measures are commonly used as a basis for Earnings Sensitivity Analysis that extends static Gap Models with assumptions on future interest rates, A\&L volume and composition, and off-balance sheet positions.

${ }^{5}$ In the final sample for interest rate risk 75 MFIs do not report A\&L according to their repricing date but with respect to contractual time to maturity only. For those MFIs, I use data on A\&L grouped according to remaining time to contractual maturity. This procedure leaves the measure of interest rate risk prone to some error. Floating rate instruments that reprice before maturity might be grouped into later, incorrect time windows according to their date of maturity. However, the dominant repricing positions on the asset side are unproblematic maturing loans and rate-sensitive holdings with the central bank. On the liability side, the MFIs mainly hold deposits that are rate-sensitive over the shorter-term anyway. The only substantial error in using maturity profiles might arise due to the fact that interim interest rate payments on borrowings from DFIs are often repriced according to LIBOR or EURIBOR before maturity. Yet, the comparability
} 
amount of RSA and RSL, the same asset classes as before remain excluded and I additionally exclude cash holdings. All liabilities are considered to be rate-sensitive, in particular demand deposits, in accordance with the measure of liquidity risk.

\subsubsection{FX Risk}

Basic FX risk arises due to mismatches between the volumes of A\&L within different foreign currency sub-portfolios of an FI's balance sheet. From an economic value perspective, a depreciating foreign currency reduces the value of foreign currency $A \& L$ (while an appreciating foreign currency does the opposite). Thus, an open long position in one foreign currency (i.e. a larger total volume of assets and FX forwards bought than liabilities and FX forwards sold) will decrease an FI's economic value measured in local currency once the foreign currency depreciates vis-à-vis the local currency. In addition to the risk caused by the different volumes of FX positions, the timing of FX positions is important. Any FX position due in the long-run bears a different amount of risk than an equivalent position due shortly if exchange rate movements feature some sort of predictability (mean reversion). In the presence of convertibility risk and transfer risk, MFIs also bear an additional amount of liquidity risk within the FX sub-portfolios (see Featherstone, Littlefield, and Mwangi 2006).

Disregarding the timing of FX positions, I rely on the Net Open Position $(N O P)$, a common method to measure FX risk exposure. I use the differ-

of repricing and maturity profiles is further supported by the fact that, for MFIs reporting both maturity and repricing profiles, the two generally do not differ significantly over the one year horizon. 
ence of all on-balance sheet FX assets and FX forwards bought and all FX liabilities and FX forwards sold in single foreign currencies (Net Exposure). I employ the most conservative aggregation method by adding the absolute values of all net positions, both positive and negative. This method rests on the assumption that exchange rates move potentially unfavorably so as to create losses for all single Net Exposures. While on an individual level this is a fair and comparable measure of FX risk exposure, it likely overstates (just like some other methods potentially understate) FX risk on an aggregate level $\sqrt[6]{6}$ The resulting sum of Net Exposures is normalized by the amount of total assets.

$$
N O P=\frac{\sum_{n=1}^{N} \mid \text { Net Exposure }_{n} \mid}{\text { Total Assets }} \text { with } n=1, \ldots, N \text { single currencies }
$$

The choice of the actual foreign currency is not always straightforward. A few countries in the sample (e.g. Kosovo, Ecuador) have adopted the Euro or the US Dollar as their primary currency without a separate legal tender. In these cases, a supposedly hard currency (Euro or US Dollar) was defined to be the local currency and is not included in the NOP. In all other cases, the local currency is the currency not included in the $N O P$, no matter the share of A\&L held in hard currencies.

\footnotetext{
${ }^{6} 34$ MFIs in the sample report their various FX positions aggregated into a single currency. In particular, 32 Latin American MFIs report all FX positions translated and aggregated into US Dollars only. Aggregation among various currencies (i.e. netting out the differences) is likely to understate true FX exposure. However, the error from this type of aggregation for Latin American MFIs is presumably small as FX positions in Latin America consist primarily of US Dollars in the first place.
} 


\subsection{Financial Risk Exposure of MFIs}

Results on the risk measures for the sub-samples of MFIs that report sufficiently detailed data are shown in Table 2, Since $L C$ is a ratio it has the tendency to generate outliers whenever the denominator approaches zero. To account for this, I censor the upper $5 \%$ of the observations that are about 10 times larger than the standard deviation of the censored sample.

Table 2. Summary Statistics - Risk Measures

\begin{tabular}{lccccc}
\hline Variable & Obs & Mean & Std. Dev. & Min & Max \\
\hline Liquidity Coverage (LC)* & 117 & 3.10 & 4.64 & 0.19 & 25.09 \\
Cumulative Interest Gap (CIG) & 132 & 0.27 & 0.20 & 0.00 & 0.80 \\
Net Open FX Position (NOP) & 97 & 0.049 & 0.08 & 0.00 & 0.42 \\
\hline Net Open FX Position incl. OBS positions & 95 & 0.051 & 0.08 & 0.00 & 0.42 \\
Share of FX Assets to Total Assets & 93 & 0.275 & 0.251 & 0.00 & 0.91 \\
Share of FX Liabilities to Total Assets & 93 & 0.280 & 0.236 & 0.00 & 0.80 \\
\hline *
\end{tabular}

${ }^{*}$ For the LC measure values above the upper $95^{\text {th }}$ percentile are censored.

MFIs' short term assets ( $\leq 30$ days) surpass short-term liabilities - both by contractual due date - threefold, on average. MFIs in the sample would thus easily pass the liquidity requirement established in Basel III eventually requiring FIs to maintain an LCR of at least one. Even more so, the sector engages in a negative level of maturity transformation. On average, MFIs in the sample face a mismatch of $27 \%$ of total assets in absolute value between RSA and RSL over the one year horizon. Even in the absence of a clear benchmark to compare with, this seems to be a rather substantial exposure towards interest rate risk. For the median sized MFI in the sample (85.3 million US Dollar in total assets) an unfavorable/favorable 100 basis points change in the interest rate, being exposed to a $27 \%$ CIG, translates into 
a loss/gain in net interest income (NII) over the one year horizon of about 115,000 US Dollar.7 Yet, interest rate risk exposure has not received much attention both in the academic and practical sphere. This might be due to the fact that interest rate risk is often perceived as potentially cutting into profits but that mitigation of the risk is not vital to the operation of an MFI. Furthermore, for most MFIs borrowing from DFIs comes at very favorable terms anyway.

MFIs are, on average, exposed to a Net Open Position of about 5\% of their total assets. The average NOP is driven by some MFIs' exposure to large amounts of FX risk and by most MFIs facing only a small NOP (distributions of the risk measures can be found in the appendix). Off-balance sheet FX positions (in many cases credit commitments) are not always reported. Including OBS positions whenever reported, however, does not change the result. Normalizing by the total amount of equity, average exposure stands at 25\%. Brom (2009) suggests that $25 \%$ NOP with respect to total equity is still a prudent level when considering only net negative positions. Given that I aggregate both positive and negative positions (maximum exposure would thus double), most MFIs pass this prudence test easily, although about $15 \%$ of all MFIs feature a non-prudent exposure. Still, nonprudent exposure is often merely a result of very low levels of equity. While

\footnotetext{
${ }^{7}$ This is under the assumption that all assets and all liabilities reprice instantaneously after half a year by the same rate, are reinvested at the new rate and there is no other change in the composition of the balance sheet. Similar to Brom $(2009)$, I use the following formula to compute the change in NII at the median:

$($ Avg. CIG $\times$ Median Total MFI Assets $) \times 100$ Basis Points $\times 6 / 12=$ Change in NII (4)

The direction of the change in NII depends on whether the actual $C I G$ and the basis points change are negative or positive. The analysis also abstracts from potential offsetting effects in time windows shorter than the one year horizon.
} 
the average $N O P$ is low, the average total share of FX A\&L is sizeable and stands at about $28 \%$ for both assets and liabilities. The usual narrative that MFIs are to a considerable extent indebted in foreign currency is true, but counterbalancing FX asset positions largely offset the exposure to FX liabilities. Lending in foreign currency by MFIs can be both supply- and demand side driven (Brown, Kirschenmann, and Ongena 2014). Nevertheless, some authors suggest that FX assets are indicative of MFIs passing FX risk on to their clients by giving out foreign currency loans, e.g. Crabb (2004). It is, however, not obvious to which extent microfinance clients who obtain FX loans actually receive income or have expenses in foreign currencies and are thus exposed to FX risk themselves. In fact, Brown, Ongena, and Yeşin (2011) suggest that retail clients borrowing in foreign currency are generally better equipped to deal with FX risk than is widely believed. Obviously, the macro data at hand is silent about the real extent of FX risk passed on to final borrowers. Comparing total FX assets and FX liabilities, instead of summing over single currencies' Net Exposures, I find that exactly half of all MFIs keep more FX assets than liabilities on their portfolio and the other half vice versa. Accordingly, the average NOP, comparing the total level of FX A\&L for every MFI, stands at less than $1 \%$ of total assets. The use of foreign currency varies considerably between regions. Eastern European and Central Asian MFIs maintain the most, while African MFIs keep the least FX A\&L in their portfolios. MFIs from East Asia and the Pacific maintain the most imbalanced FX A\&L positions (the appendix contains the distribution of FX risk among different regions). 
Figure 1 contains scatterplots that demonstrate the correlation between the three risk measures.
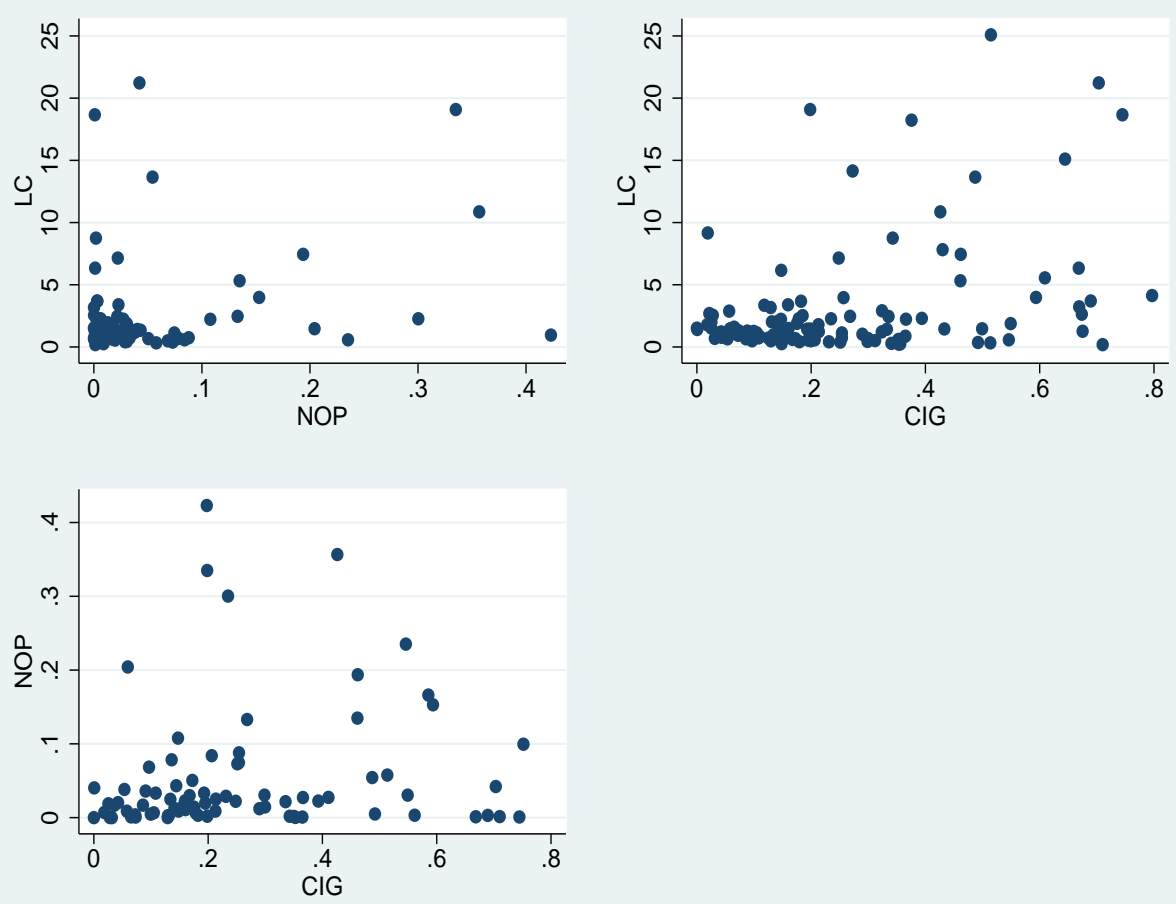

Figure 1

Scatterplots of the Risk Measures

The correlation structure is an indicator of whether MFIs might be trading off one risk for another. In particular, we might expect MFIs to trade off liquidity risk for FX risk by either relying on long-term hard currency financing or local currency deposits for funding. However, I find only weak support for this hypothesis in the data. The correlation between NOP and $\mathrm{LC}$ is 0.262 . 


\subsection{Methodology}

\subsubsection{Explanatory Variables}

Besides estimating the microfinance sector's overall exposure to financial risk, this study also asks in what way the exposure is linked to the legal statuses of MFIs and the legal environments in which they operate. The main explanatory variables (also widely perceived to be the most relevant policy variables) I use to estimate the effect of institutional characteristics on risk exposure are an MFIs legal status, as provided in the MIX database, and the quality of local regulation. To measure the impact of regulatory quality, I rely on the data provided by Barth, Caprio Jr., and Levine (2013). Their database on bank regulation and supervision covers 180 countries in four surveys between 2000 and 2011, whereby I always use the most recent data available. In particular, I use the database's sub-category Official Supervisory Power that aims to capture "whether the supervisory authorities have the authority to take specific actions to prevent and correct problems" (Barth, Caprio Jr., and Levine 2013). The bank regulation database is naturally focused on institutions governed by banking laws. In order to avoid missing the effects of regulation on legal statuses other than banks by construction, I use an alternative broader measure of regulatory quality provided by the Worldwide Governance Indicators (WGI) Project (Kaufmann, Kraay, and Mastruzzi 2010). Their governance indicator, which is available for all countries in the sample, covers six dimensions (Voice and Accountability, Political Stability and Absence of Violence, Government Effectiveness, Regulatory Quality, Rule of Law and Control of Corruption) that affect not 
only banks but all legal types of MFIs, whereby I use the Regulatory Quality sub-index from 2011. As a third alternative, I consider data from the 2011 Global Microscope on the business environment in microfinance in 55 countries (EIU 2011), a joint initiative of the Economist Intelligence Unit (EIU) and other DFIs. For countries that have no rating in the report, I use their regional average. It is important to note that the main results do not change for any of the three alternatives and, in what follows, only the results for the bank regulation database from Barth, Caprio Jr., and Levine (2013) are reported (other results are available upon request).

\subsubsection{Control Variables and Selection Bias}

I control for factors that are reasonably expected to influence risk taking and/or to be correlated with an MFI's legal status or regulatory quality. Age and size capture the effects of an MFI's maturing process and I expect larger and older MFIs to have more sound risk management and thus lower average exposure. To proxy managerial quality, but also competition effects, the return on assets (ROA) is included as a control variable. Less competition will generally allow MFIs to generate a higher ROA. However - at least in the short-run - riskier business models might also be correlated with a higher ROA. I additionally include regional dummies to capture the effects of different MFI business models across regions that might correlate with MFIs' risk preferences and/or a different attitude of investors towards certain regions. Finally, different exchange rate volatilities suggest different levels of FX risk exposure that can still be considered prudent. In order to control for different exchange rate volatilities caused by exchange rate regimes, I 
include a dummy for non-free-floating currencies in the regressions concerned with FX risk exposure. The data on currency regimes, where a value of one is assigned to non-free-floating currencies, was taken from the IMF's Annual Report on Exchange Arrangements and Exchange Restrictions in 2011 (available at www.imf.org/external/pubs/ft/ar/2011/eng/pdf/a2.pdf). All other control variables are obtained from the MIX database for fiscal year-end 2011.

Summary statistics that are not reported here show that the level of deposits in the sample is related to an MFI's legal status, as Banks are almost always deposit-taking. On average, Banks in the sample fund $56 \%$ of their total assets via deposits, NBFIs $26 \%$ and NGOs, Credit Unions and Cooperatives $31 \%$. Also, an MFI's profit status is almost perfectly correlated with its legal status. In particular, almost all Banks in the sample state to operate for-profit while NGOs, Credit Unions and Cooperatives in the sample never do. To avoid multi-collinearity, an MFI's profit status and whether an MFI accepts deposits or not are thus discarded as control variables. The correlation structure of other controls used does not suggest multi-collinearity problems (Table A1 in the appendix states all the pairwise correlations between the risk measures and MFI features.).

The final samples of reporting MFIs at hand necessarily suffer from selection bias. To discuss selection bias, Table 3 summarizes descriptive statistics separately for the sample of MFIs that report in sufficient detail to construct at least one of the three risk measures (the selection) and those that do not 
publish audited financial statements at all or do not report in sufficient detail.

Interestingly, reporting MFIs and non-reporting MFIs are quite similar with respect to most of their characteristics. Similarity of MFIs reporting and not reporting with regard to most portfolio characteristics suggests that selection bias in the final samples of reporting MFIs is contained. Although the sample for the different risk measures always somewhat changes, this result also holds when separating MFIs into reporting and non-reporting according to the three different risk measures respectively. Using t-tests for the continuous variables, the hypothesis of an equal mean between the two groups is only rejected for the regulatory quality index taken from the Barth, Caprio Jr., and Levine (2013) database. If we accredited a monitoring role to depositors, we would also expect deposit-taking MFIs to be more likely to report details on their risk exposure. Yet, there is no such effect to be found in the data. Table A2 in the appendix presents results from a Probit model on the differences between MFIs reporting and MFIs not reporting in detail for any of the risk measures. Results show that being an Eastern European MFI significantly increases the likelihood of reporting compared to other regions for all risk categories. I suggest that the high reporting quality of Eastern European MFIs might be an outcome of their close ties with European investors. Due to a lack of consistent data on how closely MFIs are linked to foreign investors, I am, however, not able to directly test this hypothesis. Results also show that differences between the reporting and non-reporting groups of MFIs are uncorrelated with most basic MFI portfolio characteristics (details can be found in the appendix). The fact 


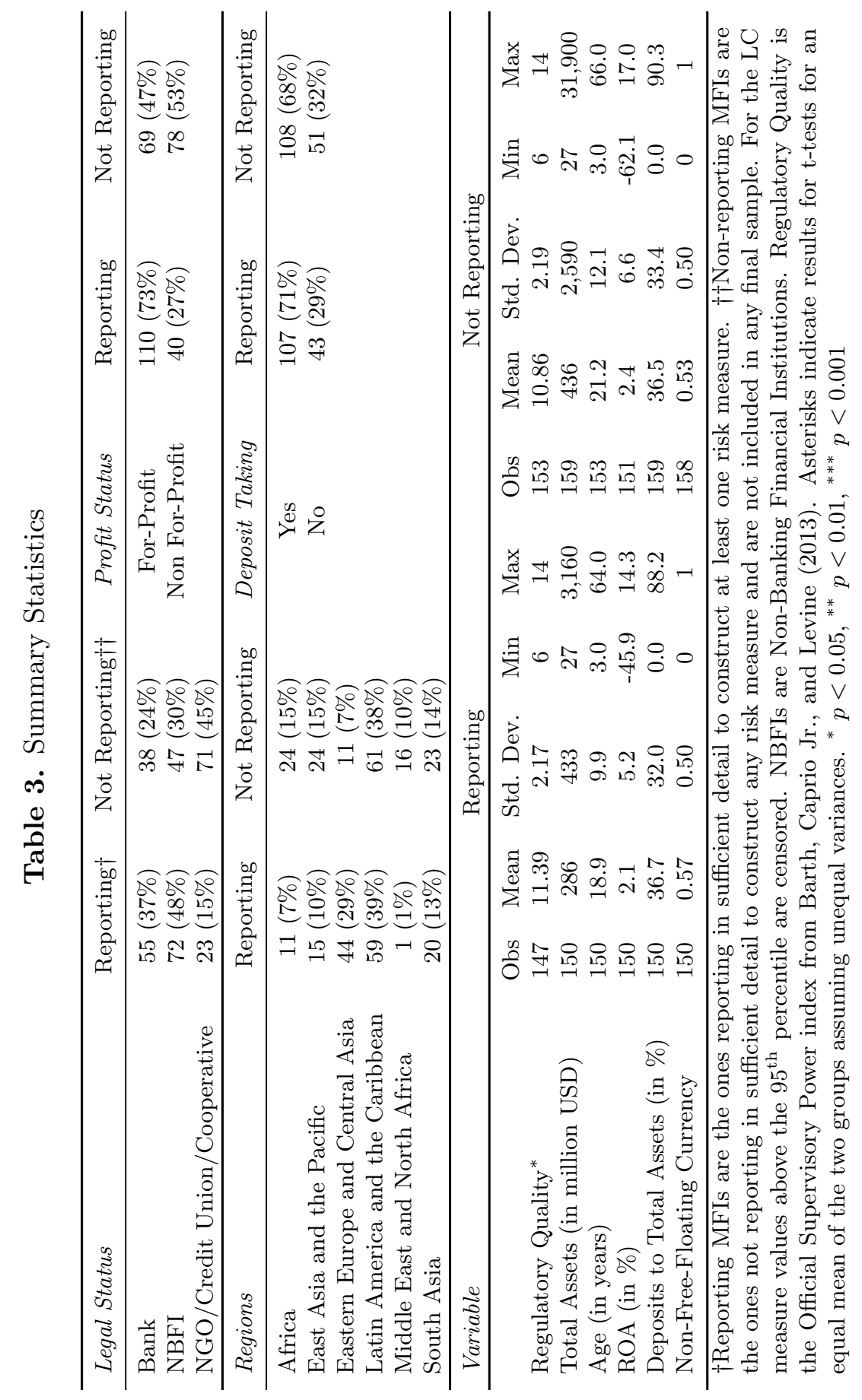


that selection bias is limited, is also supported by the idea that it seems unlikely for an MFI to adjust reporting behavior to the level of exposure to liquidity, interest rate or FX risk. To further support this, I estimate a Heckman selection correction model for the final estimation of legal status and regulation on liquidity risk exposure. I use the MIX's reporting quality index (the diamonds) that are a function of how much data an MFI has provided to the MIX database, as an instrument. Again, the bias-correction model does not suggest the presence of significant selection bias (results are available upon request).

\subsubsection{Estimation Method}

My measures of interest rate risk $(C I G)$ and FX risk $(N O P)$ are normalized by total assets and thus fractions bounded by the unit interval. Therefore, the determinants of interest rate and FX risk exposure cannot be consistently estimated using a linear model. An increasingly popular method of modeling dependent variables defined on the standard unit interval is the fractionallogit approach introduced by Papke and Wooldridge (1996). Their approach imposes the following assumption on the conditional mean and chooses $G(\cdot)$ to be the logistic function:

$$
\mathbb{E}(Y \mid \mathbf{X})=G(\mathbf{X} \beta)
$$

For the $L C$ regression, I use a simple linear model that is nested in this more general assumption on the conditional mean when instead of the logistic link function the identity link function is used. As an alternative to 
the fractional-logit approach, I employ beta regressions and the main results are not sensitive to this choice 8 I use dummy coding for the categorical variables and define Africa and Banks as the baseline categories for region and legal status. I perform F-tests to test for the joint significance of the categorical variables on the mean of the outcome variables.

\section{Results}

Table 4 states the summary statistics for the risk measures by different legal status. Banks are exposed to the highest level of liquidity risk (the lowest $L C)$ and fund the highest share of their assets with FX liabilities. However, Banks also hold more FX assets than other legal types. NGOs, Credit Unions and Cooperatives feature the most imbalanced balance sheets with respect to RSA and RSL, while Banks are exposed to the lowest level of interest rate risk among all legal statuses. Not reported regression results on the determinants of FX A\&L volumes in MFIs' portfolios show that NBFIs hold a lower share of FX assets and FX liabilities even when controlling for other portfolio characteristics. However, in a fully specified model, dummies for the region fully explain the difference in volumes of FX A\&L between the legal statuses (results are available upon request). This suggests that the use of FX A\&L is largely a function of the region an MFI operates in. The regional impact on FX A\&L volumes is likely due to differences in the extent local economies make use of foreign currency and possibly also due

\footnotetext{
${ }^{8} \mathrm{~A}$ good introduction into fractional regression models and both methods can be found in Ramalho, Ramalho, and Murteira (2011) and the sources within. For details of the estimation procedure see the STATA commands $g l m$ and betafit.
} 
to investors' different strategies for certain regions.

Table 4. Summary Statistics - Risk Measures by Legal Status

\begin{tabular}{|c|c|c|c|c|c|}
\hline Variable & Obs & Mean & Std. Dev. & Min & $\operatorname{Max}$ \\
\hline \multicolumn{6}{|c|}{ Legal Status: Bank } \\
\hline $\mathrm{LC}^{*}$ & 51 & 1.34 & 0.97 & 0.19 & 4.13 \\
\hline CIG & 54 & 0.21 & 0.18 & 0.00 & 0.80 \\
\hline NOP & 36 & 0.03 & 0.04 & 0.00 & 0.20 \\
\hline FX Assets (share) & 35 & 0.35 & 0.25 & 0.00 & 0.79 \\
\hline FX Liabil. (share) & 35 & 0.35 & 0.25 & 0.00 & 0.80 \\
\hline \multicolumn{6}{|c|}{ Legal Status: NBFI } \\
\hline $\mathrm{LC}^{*}$ & 47 & 5.01 & 6.42 & 0.27 & 25.09 \\
\hline CIG & 57 & 0.28 & 0.20 & 0.00 & 0.74 \\
\hline $\mathrm{NOP}$ & 49 & 0.04 & 0.08 & 0.00 & 0.36 \\
\hline FX Assets (share) & 46 & 0.21 & 0.22 & 0.00 & 0.73 \\
\hline FX Liabil. (share) & 46 & 0.22 & 0.21 & 0.00 & 0.72 \\
\hline \multicolumn{6}{|c|}{ Legal Status: NGO/CreditUnion/Cooperative } \\
\hline $\mathrm{LC}^{*}$ & 19 & 3.12 & 3.53 & 0.23 & 13.65 \\
\hline CIG & 21 & 0.37 & 0.19 & 0.09 & 0.75 \\
\hline NOP & 12 & 0.13 & 0.13 & 0.00 & 0.42 \\
\hline FX Assets (share) & 12 & 0.29 & 0.33 & 0.00 & 0.91 \\
\hline FX Liabil. (share) & 12 & 0.33 & 0.24 & 0.00 & 0.67 \\
\hline
\end{tabular}

Table 5 reports estimation results on the determinants of risk exposure for the three different risk measures. I apply a log-transformation to the LC measure to achieve more efficient estimates. Results in columns (1)-(3) thus report exponentiated coefficients. Values smaller than one indicate a negative, values larger than one a positive influence. Results for the baseline $L C$ regression suggest that the group of Non-Banking Financial Institutions (NBFIs) features a lower liquidity risk than Banks do (results suggest that the liquidity coverage more than doubles). The difference between Banks and NGOs, Credit Unions and Cooperatives is not significant. The effect be- 
tween NBFIs and Banks does not seem to be fully explained by the fact that Banks in the sample rely much more on deposits than NBFIs do. Repeating the same regression for the sub-sample of only deposit-taking institutions, NBFIs still feature significantly less liquidity risk than Banks (results are reported in Table A3 in the appendix). The coefficient on regulatory quality is insignificant in all specifications. Adding controls, I find that larger MFIs are exposed to a higher level of liquidity risk. In the full specification, risk exposure varies significantly between regions, and regions explain part of the difference between NBFIs and Banks. However, even in the full specification liquidity coverage of NBFIs is more than $160 \%$ that of Banks. The economic size of the effect of the regions obviously depends on the choice of the base category Africa. Yet, the regional dummies are jointly significant at the 5\% level (F-test).

Baseline results on interest rate risk suggest that NGOs, Credit Unions and Cooperatives feature significantly higher levels of interest rate risk, but again there is no effect of regulatory quality on risk exposure. In the full specification, marginal effects show that an increase in ROA of 1 percentage point is accompanied by an increase in the $C I G$ of about 1.6 percentage points. With respect to interest rate risk there is thus some evidence that higher returns and better financial performance - or lower competition - are accompanied by larger risk taking. A larger $C I G$ can indeed be a rational choice given larger differences on the interest spread between A\&L. Most importantly, however, by including the set of controls, significant effects of the legal status on $C I G$ are fully captured by the controls. An F-test for a uniformly zero effect of all regions is rejected at the $5 \%$ level. 


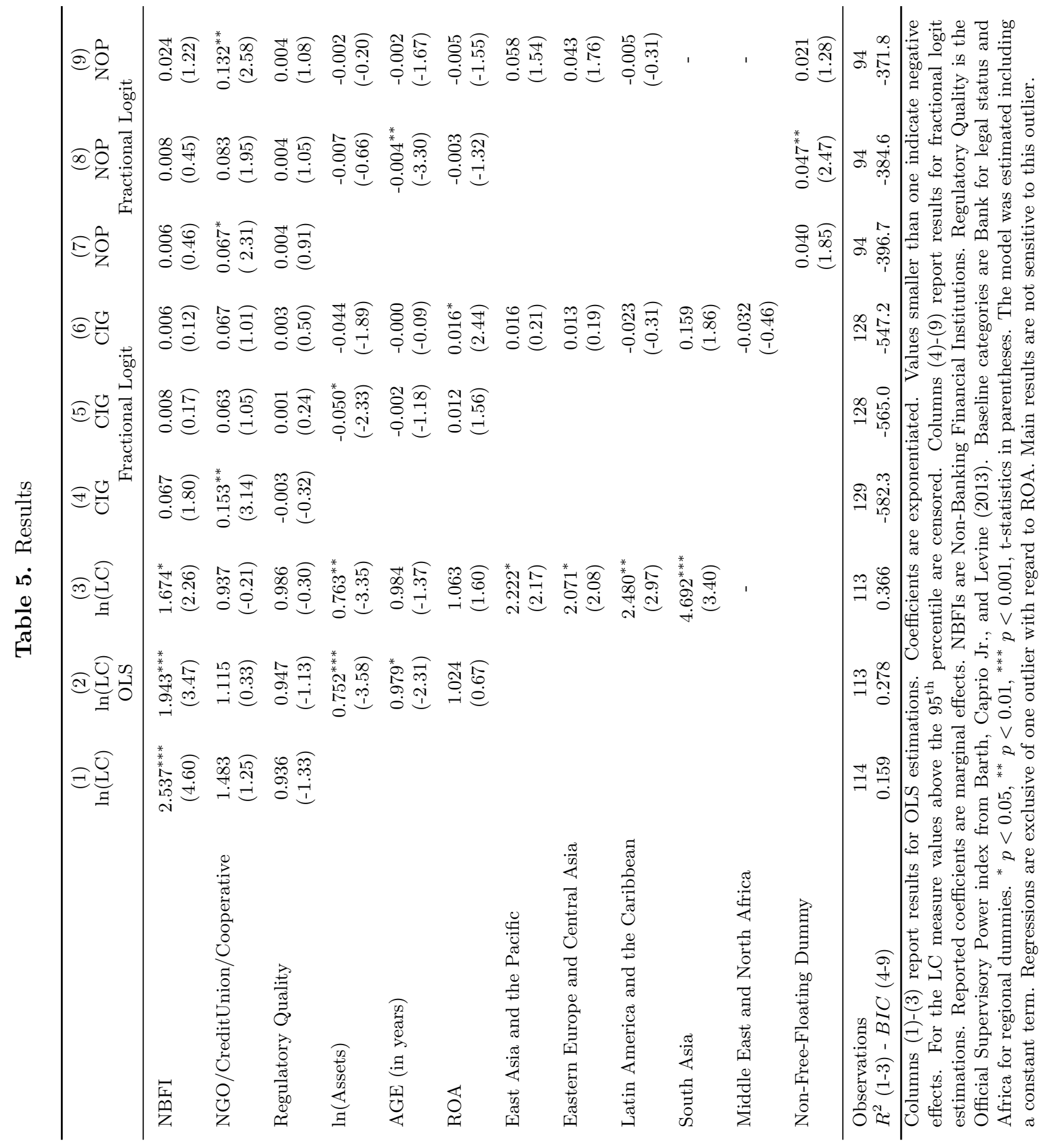


The NOP specifications show that alternative legal statuses are exposed to a higher level of FX risk than Banks (about 7 - 13 percentage points depending on the model specification), despite the fact that NGOs, Credit Unions and Cooperatives maintain less FX liabilities (see Table 4). This suggests that NGOs, Credit Unions and Cooperatives are not as well equipped to offset exposure with matching FX asset positions, possibly also due to a different demand for FX products from their client base. The difference of about 7 - 13 percentage points is also meaningful economically, as it constitutes a difference of at least one standard deviation in the average NOP. There is no significant difference between Banks and NBFIs and regulatory quality is again unrelated to risk exposure. The dummy for a non-free-floating currency arrangement has the expected sign - MFIs operating in non-floating currency economies are exposed to a higher level of FX risk - but is not always significant. Regional dummies are highly correlated with currency regimes and pick up that effect in the full specification. An F-test shows that regional affiliation is jointly significant at the $1 \%$ level.

A few salient results on the influence of institutional features on risk exposure emerge across the three risk classes. On the one hand, results suggest no significant link between the quality of local regulation and risk exposure. Results are supportive of Mersland and Strøm (2009) and of much of the related literature in that regulatory quality seems to play only a minor role in determining MFIs' business models. Nonetheless, given the seemingly low level of liquidity risk for the sector in total, it might well be that regulators simply do not see sufficient necessity for intervention 
(which would be somewhat contradictory to the plethora of measures taken by DFIs). On the other hand, results show that differences in risk exposure other than credit risk can matter when comparing the performance and outreach of different legal statuses of MFIs. The data shows that Banks are exposed to a higher level of liquidity risk than NBFIs, which is likely the composite effect of Banks relying more on deposits for funding but also of other institutional features. At first sight, the result that Banks are exposed to less FX risk than NGOs, Credit Unions and Cooperatives could be caused by different investors' attainment towards MFIs with different legal statuses, for example, due to the fact that donors shun from lending to non-Banks in local currency. However, the observation that Banks actually fund a higher share of assets via FX liabilities but are still exposed to less FX risk suggests that Banks might have access to better management tools to mitigate FX risk.

Regional affiliation has a significant impact on all measures of risk exposure. Given that an MFI's region is not a policy variable on a micro level, most of previous research has naturally focused on the influence of legal status or regulatory institutions. However, I find that the neglect of regional effects might be unwarranted in cross-regional data sets. At first glance, strong regional effects are surprising given that supra-regional investor initiatives like ProCredit or FINCA have been implementing highly similar institutions across the world for about 30 years now. Yet, it seems that, despite the standardization in microfinance, banking traditions in different parts of the world have been shaping MFIs' business models up to now. 


\section{Conclusion}

This study offers novel evidence on the exposure of the microfinance sector to liquidity, interest rate and FX risk by presenting descriptive evidence on the sector's overall risk exposure and by estimating which institutional features correlate with higher levels of risk.

Currently, the sector in total engages in negative maturity transformation and the world's largest MFIs, on average, face no liquidity risk. From a developmental point of view (rather than from a risk management perspective), the outstandingly high liquidity coverage might not always be desirable because long-term lending by MFIs often constitutes an explicit development goal. Due to the imbalanced maturity structure in MFIs' portfolios (borrow

long and lend short), exposure to interest rate risk is considerable. Exposure to FX risk is - due to offsetting FX asset positions - lower than most market observers tend to believe. In particular, Banks are well equipped to counterbalance the large share of FX liabilities within their portfolios. While risk exposure varies among different legal statuses, there is no effect of local regulation on exposure to financial risk to be found in the data.

Despite the exposure of single institutions to considerable FX or liquidity risk, calls for an expansion of systemic actions against these risks in microfinance seem to be lacking foundation in the actual data. On an aggregate level, I find it highly unlikely that liquidity risk or FX risk effectively constrain MFIs from expanding their lending activities towards larger and more long-term microfinance portfolios. The data at hand is obviously silent about whether low levels of risk exposure are merely the success of effective 
measures taken against financial risk in the past. Still, on an aggregate level, there is not much reason to expect MFIs to expand their lending activities - both in volume and towards longer-term credit - due to policies geared towards liquidity or FX risk. Without much doubt, the development community should expect larger benefits from policy measures that are targeted towards risks that effectively constrain MFIs' lending. Meanwhile, further research attempts on financial risk in microfinance will highly profit from an increase in cross-regional data availability, mostly from data on the actual sources of funding grouped into DFI, commercial bank and/or local sources, and the standardized reporting of A\&L maturities to MIX. 


\section{References}

Abrams, Julie and Jerome Prieur (2011). An Empirical Analysis of Foreign Exchange Risk Exposure in Microfinance. MFX and FMO. URL: www . microrate . com/media/docs / investment/MFX_Risky-Business_ 2011.pdf.

Barth, James R., Gerard Caprio Jr., and Ross Levine (2013). "Bank regulation and supervision in 180 countries from 1999 to 2011". In: Journal of Financial Economic Policy 5(1), pp. 111-219. DOI: $10.1108 /$ 17576381311329661

BCBS (2004). Principles for the Management and Supervision of Interest Rate Risk. Bank for International Settlements. URL: www.bis.org/publ/ bcbs108.pdf

- (2008). Principles for Sound Liquidity Risk Management and Supervision. Bank for International Settlements. URL: www . bis . org/publ/ $\mathrm{bcbs} 144 \cdot \mathrm{pdf}$

- (2013). Basel III: The Liquidity Coverage Ratio and Liquidity Risk Monitoring Tools. Bank for International Settlements. URL: www. bis.org/ publ/bcbs238.pdf.

Brewer, Elijah (1985). "Bank Gap Management and the Use of Financial Futures". In: Economic Perspectives, Federal Reserve Bank of Chicago $9(2)$, pp. $12-22$.

Brom, Karla (2009). "Asset and Liability Management for Deposit-Taking Microfinance Institutions". In: CGAP Focus Note (55). 
Brown, Martin, Karolin Kirschenmann, and Steven Ongena (2014). "Bank Funding, Securitization, and Loan Terms: Evidence from Foreign Currency Lending". In: Journal of Money, Credit and Banking 46(7), pp. 15011534. DOI: $10.1111 / \mathrm{jmcb} .12147$.

Brown, Martin, Steven Ongena, and Pinar Yeşin (2011). "Foreign Currency Borrowing by Small Firms in the Transition Economies". In: Journal of Financial Intermediation 20(3), pp. 285-302. DOI: 10.1016/j·jfi. 2010.12.001.

Crabb, Peter R. (2004). "Foreign Exchange Risk Management Practices of Microfinance Institutions". In: Journal of Microfinance 6(2), pp. 51-64. Cull, Robert, Asli Demirgüç-Kunt, and Jonathan Morduch (2011). "Does Regulatory Supervision Curtail Microfinance Profitability and Outreach?" In: World Development 39(6), pp. 949-965. DOI: 10.1016/j . worlddev. 2009.10 .016

EIU (2011). Global Microscope on the Microfinance Business Environment 2011. Economist Intelligence Unit. URL: WwW.eiu.com\microscope2011. Featherstone, Scott, Elizabeth Littlefield, and Patricia Mwangi (2006). "Foreign Exchange Rate Risk in Microfinance: What is it and how can it be managed?" In: CGAP Focus Note (31).

Hartarska, Valentina and Denis Nadolnyak (2007). "Do Regulated Microfinance Institutions Achieve Better Sustainability and Outreach? Crosscountry Evidence". In: Applied Economics 39(10), pp. 1207-1222. DOI: $10.1080 / 00036840500461840$. 
Kaufmann, Daniel, Aart Kraay, and Massimo Mastruzzi (2010). "The Worldwide Governance Indicators: Methodology and Analytical Issues". In: World Bank Policy Research Working Paper (5430).

Koch, Timothy W. and Scott S. McDonald (2009). Bank Management. 4th ed. Harcourt Brace \& Company, Orlando.

Lahaye, Estelle, Ralitsa Rizvanolli, and Edlira Dashi (2012). Current Trends in Cross-Border Funding for Microfinance. URL: http://www.cgap.org/ publications/current-trends-cross-border-funding-microfinance.

Lützenkirchen, Cédric and Christian Weistroffer (2012). Microfinance in Evolution. An Industry between Crisis and Advancement. DB Research. URL: WWW.dbresearch.com.

Mersland, Roy (2009). "The Cost of Ownership in Microfinance Organizations". In: World Development 37(2), pp. 469-478. DOI: $10.1016 / \mathrm{j}$. worlddev.2008.03.006.

Mersland, Roy and Reidar Øystein Strøm (2008). "Performance and Tradeoffs in Microfinance Organisations - Does Ownership Matter?" In: Journal of International Development 20(5), pp. 598-612. DOI: 10.1002 / jid.1432.

— (2009). "Performance and Governance in Microfinance Institutions". In: Journal of Banking \& Finance 33(4), pp. 662-669. DOI: 10.1016/j . jbankfin.2008.11.009.

Papke, Leslie E. and Jeffrey M. Wooldridge (1996). "Econometric Methods for Fractional Response Variables with an Application to 401(K) Plan Participation Rates". In: Journal of Applied Econometrics 11(6), 
pp. 619-32. DOI: 10.1002/(SICI) 1099-1255(199611) 11:6<619: :AID-

JAE418>3.0.CO;2-1.

Ramalho, Esmeralda A., Joaquim J.S. Ramalho, and José M.R. Murteira (2011). "Alternative Estimating And Testing Empirical Strategies For Fractional Regression Models". In: Journal of Economic Surveys 25(1), pp. 19-68. DOI: $10.1111 / \mathrm{j} .1467-6419.2009 .00602 . \mathrm{x}$.

Reille, Xavier, Daniel Rozas, and Sarah Forster (2011). "Foreign Capital Investment in Microfinance: Reassessing Financial and Social Returns". In: CGAP Focus Note (71).

Van Greuning, Hennie and Sonja Brajovic-Bratanovic (2009). Analyzing Banking Risk. 3rd ed. World Bank Publications.

Winkler, Adalbert and Charlotte Wagner (2012). "The Financial Crisis a Microfinance Perspective". In: Swiss Journal of Business Research and Practice 66(4), pp. 324-339. 


\section{Appendix}

Table A1. Pairwise Correlations Between Main Variables and Controls

\begin{tabular}{lccccccccc}
\hline & LC* & CIG & NOP & Regul & Peg & Assets & Age & De/As & ROA \\
\hline LC* & 1 & & & & & & & & \\
CIG & 0.402 & 1 & & & & & & & \\
NOP & 0.262 & 0.148 & 1 & & & & & & \\
Regul & -0.126 & -0.029 & 0.046 & 1 & & & & \\
Peg & -0.105 & 0.047 & 0.264 & -0.176 & 1 & & & \\
Assets & -0.213 & -0.204 & -0.181 & 0.030 & 0.026 & 1 & & \\
Age & -0.188 & -0.052 & -0.178 & 0.024 & -0.026 & -0.019 & 1 & & \\
De/As & -0.487 & -0.442 & -0.395 & 0.203 & 0.032 & 0.126 & 0.274 & 1 & \\
ROA & 0.100 & 0.234 & -0.029 & -0.006 & 0.083 & -0.016 & 0.014 & -0.056 & 1
\end{tabular}

*For all correlations involving LC values above the $95^{\text {th }}$ percentile are censored. Abbreviations are: Regul = Regulatory Quality, the Official Supervisory Power index from Barth, Caprio Jr., and Levine (2013), Peg = Dummy for Non-Free-Floating Currencies, Dep/As = Deposits to Assets Ratio 
Table A2. Selection Model

\begin{tabular}{|c|c|}
\hline & $\begin{array}{c}\text { (1) } \\
\text { Selection Dummy }\end{array}$ \\
\hline NBFI & $\begin{array}{l}0.025 \\
(0.35)\end{array}$ \\
\hline NGO/CreditUnion/Cooperative & $\begin{array}{l}-0.211^{*} \\
(-2.52)\end{array}$ \\
\hline Regulatory Quality & $\begin{array}{l}0.018 \\
(1.32)\end{array}$ \\
\hline External Audit Strength & $\begin{array}{c}0.132^{* *} \\
(2.75)\end{array}$ \\
\hline $\ln$ (Assets) & $\begin{array}{l}0.030 \\
(1.22)\end{array}$ \\
\hline AGE (in years) & $\begin{array}{l}-0.001 \\
(-0.27)\end{array}$ \\
\hline ROA & $\begin{array}{l}0.001 \\
(0.28)\end{array}$ \\
\hline East Asia and the Pacific & $\begin{array}{l}0.023 \\
(0.19)\end{array}$ \\
\hline Eastern Europe and Central Asia & $\begin{array}{c}0.442^{* * *} \\
(4.59)\end{array}$ \\
\hline Latin America and the Caribbean & $\begin{array}{l}0.047 \\
(0.48)\end{array}$ \\
\hline Middle East and North Africa & $\begin{array}{r}-0.305^{*} \\
(-2.50)\end{array}$ \\
\hline South Asia & $\begin{array}{l}0.008 \\
(0.07)\end{array}$ \\
\hline $\begin{array}{l}\text { Observations } \\
\text { Pseudo } R^{2}\end{array}$ & $\begin{array}{c}287 \\
0.188\end{array}$ \\
\hline \multicolumn{2}{|c|}{$\begin{array}{l}\text { Table reports results from a Probit model on which MFIs report in } \\
\text { sufficient detail to construct any of the single risk measures. NBFIs are } \\
\text { Non-Banking Financial Institutions. Regulatory Quality is the Official } \\
\text { Supervisory Power index from Barth, Caprio Jr., and Levine }(2013) \text {. } \\
\text { Baseline categories are Bank for legal status and Africa for regional } \\
\text { dummies. Results are marginal effects. }{ }^{*} p<0.05,{ }^{* *} p<0.01,{ }^{* * *} \\
p<0.001, t \text {-statistics in parentheses. }\end{array}$} \\
\hline
\end{tabular}


To achieve a more targeted measure of regulatory quality on detailed risk reporting, the Probit model for the likelihood of doing detailed risk reporting or not (for any of the three risks) includes the Strength of External Audit category from the Barth, Caprio Jr., and Levine (2013) bank regulation database. The index is the sum of affirmative answers to seven questions on the effectivenes of external audits of banks (Barth, Caprio Jr., and Levine 2013). Eastern European MFIs are more likely to report for all sub-samples of risk. Only the difference with respect to African MFIs is inferred from the table but the effect remains highly significant for all other choices of base categories as well. F-tests for joint significance of the categorical variables show that the region has a significant effect on the likelihood of being part of the selection at the $1 \%$ level. Results also show that NGOs, Credit Unions and Cooperatives are on average less likely than Banks to report in sufficient detail to construct any of the three risk measures. Furthermore, whenever local regulation on external auditing procedures is stricter, the likelihood of detailed reporting increases. Results for the same regression on the sub-samples of the single risk measures' selections are similar, although the difference between NGOs, Credit Unions and Cooperatives and Banks is not significantly different from zero in the NOP sample of MFIs. Additionally, larger MFI are somewhat more likely to report in detail in the $L C$ sample (results are available upon request). 

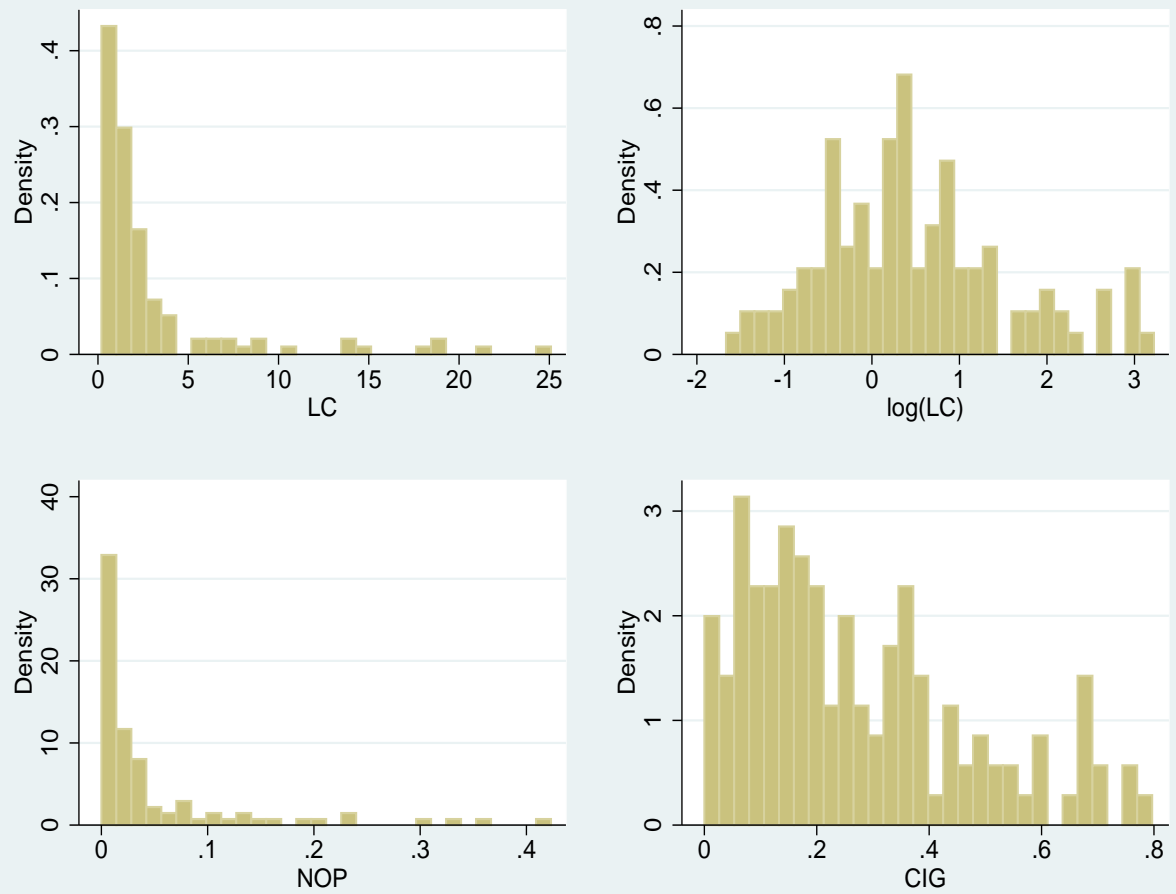

Figure A1

Densities of the Risk Measures (LC measure censored) 


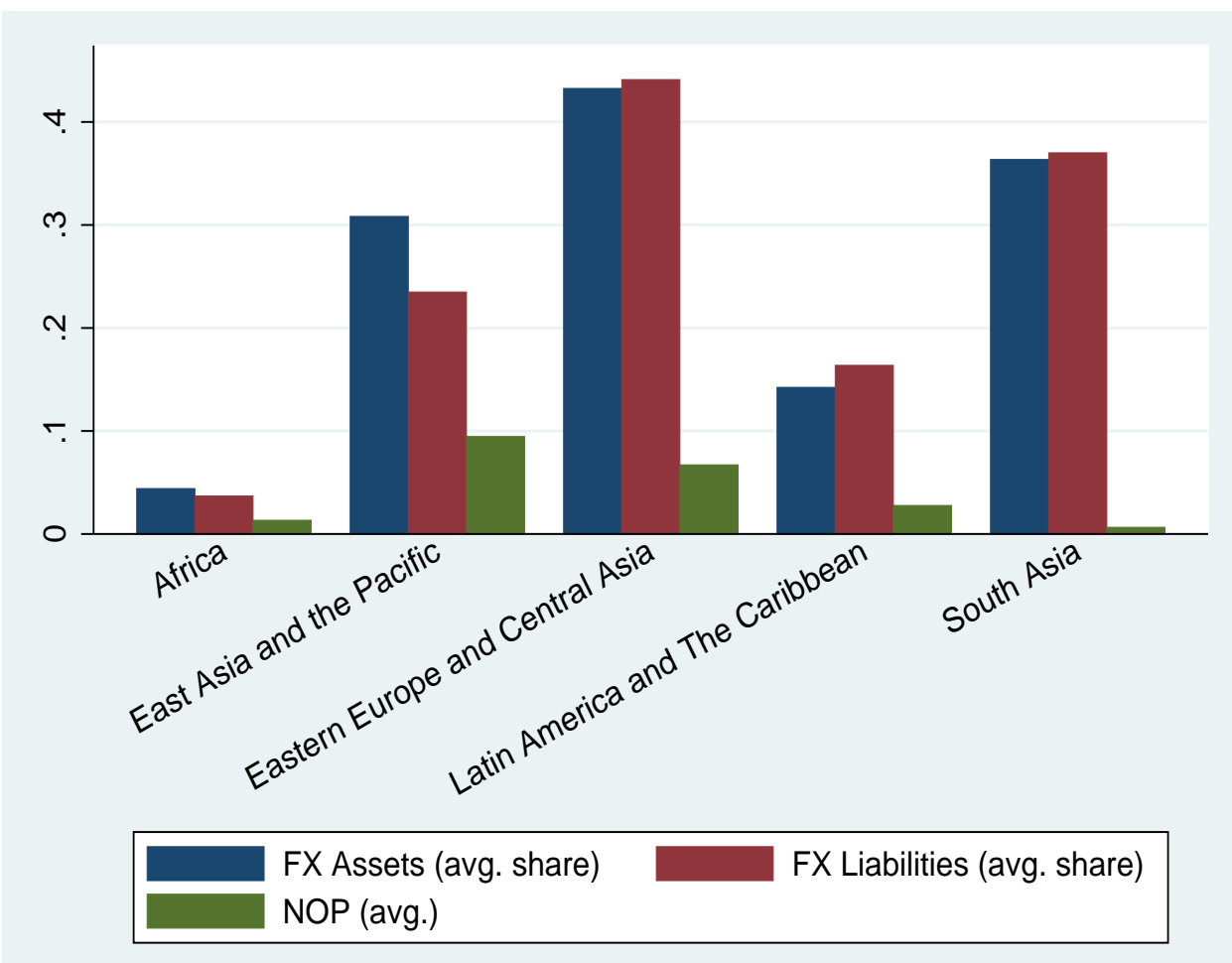

Figure A2

FX Exposure by Region 
Table A3. Results - Deposit-Taking Only

\begin{tabular}{|c|c|c|c|}
\hline & $\begin{array}{c}(1) \\
\ln (\mathrm{LC})\end{array}$ & $\begin{array}{c}(2) \\
\ln (\mathrm{LC})\end{array}$ & $\begin{array}{c}(3) \\
\ln (\mathrm{LC})\end{array}$ \\
\hline NBFI & $\begin{array}{c}2.119^{* * *} \\
(3.56)\end{array}$ & $\begin{array}{l}1.628^{*} \\
(2.57)\end{array}$ & $\begin{array}{l}1.544^{*} \\
(1.99)\end{array}$ \\
\hline NGO/CreditUnion/Cooperative & $\begin{array}{c}0.889 \\
(-0.28)\end{array}$ & $\begin{array}{c}0.652 \\
(-1.02)\end{array}$ & $\begin{array}{c}0.577 \\
(-1.57)\end{array}$ \\
\hline Regulatory Quality & $\begin{array}{c}0.941 \\
(-1.40)\end{array}$ & $\begin{array}{c}0.946 \\
(-1.33)\end{array}$ & $\begin{array}{c}0.983 \\
(-0.43)\end{array}$ \\
\hline $\ln$ (Assets) & & $\begin{array}{c}0.742^{* * *} \\
(-3.62)\end{array}$ & $\begin{array}{c}0.781^{* *} \\
(-3.06)\end{array}$ \\
\hline AGE (in years) & & $\begin{array}{c}0.988 \\
(-1.37)\end{array}$ & $\begin{array}{c}0.997 \\
(-0.27)\end{array}$ \\
\hline $\mathrm{ROA}$ & & $\begin{array}{l}1.097 \\
(1.80)\end{array}$ & $\begin{array}{l}1.130^{*} \\
(2.62)\end{array}$ \\
\hline East Asia and the Pacific & & & $\begin{array}{l}2.528^{*} \\
(2.64)\end{array}$ \\
\hline Eastern Europe and Central Asia & & & $\begin{array}{c}2.414^{* *} \\
(2.91)\end{array}$ \\
\hline Latin America and the Caribbean & & & $\begin{array}{c}2.293^{* *} \\
(2.96)\end{array}$ \\
\hline South Asia & & & $\begin{array}{c}5.576^{* * *} \\
(3.65)\end{array}$ \\
\hline Constant & $\begin{array}{l}2.019 \\
(1.48)\end{array}$ & $\begin{array}{c}673.7^{* * *} \\
(3.84)\end{array}$ & $\begin{array}{l}53.16^{*} \\
(2.34)\end{array}$ \\
\hline $\begin{array}{l}\text { Observations } \\
R^{2}\end{array}$ & $\begin{array}{c}89 \\
0.145\end{array}$ & $\begin{array}{c}89 \\
0.272\end{array}$ & $\begin{array}{c}89 \\
0.423\end{array}$ \\
\hline
\end{tabular}

Columns (1)-(3) report results for OLS estimations. Coefficients are exponentiated. Values smaller than one indicate negative effects. For the LC measure values above the $95^{\text {th }}$ percentile are censored. NBFIs are Non-Banking Financial Institutions. Regulatory Quality is the Official Supervisory Power index from Barth, Caprio Jr., and Levine (2013). Baseline categories are Bank for legal status and Africa for regional dummies. ${ }^{*} p<0.05,{ }^{* *} p<0.01,{ }^{* * *} p<0.001$, t-statistics in parentheses. 